\title{
Periodontal and dental conditions of a school population in a volcanic region of Tanzania with highly fluoridated community drinking water
}

\author{
Jaume Miranda-Rius ${ }^{1,2}$, Lluís Brunet-Llobet ${ }^{2,3}$, Eduard Lahor-Soler ${ }^{1,2}$, Ombeni Mrina ${ }^{4}$, \\ Elias I Mashala ${ }^{5}$, Michael J Mahande ${ }^{6}$
}

1. Department of Odontostomatology. Faculty of Medicine and Health Sciences. University of Barcelona, Barcelona, Spain.

2. Hospital Dentistry, Clinical Orthodontics \& Periodontal Medicine Research Group (HDECORPEMrg), Institut de Recerca Sant Joan de Déu (IRSJD), Barcelona, Spain.

3. Department of Pediatric Dentistry. Hospital Sant Joan de Déu. University of Barcelona, Barcelona, Spain.

4. Dental \& Oral Department, Soweto General Hospital, Arusha, United Republic of Tanzania.

5. Department of Orthopedic Surgery and Traumatology, Mount Meru Regional Hospital, Arusha, United Republic of Tanzania.

6. Department of Epidemiology and Biostatistics. Institute of Public Health. Kilimanjaro Christian Medical University College (KCMU College), Moshi, United Republic of Tanzania.

\begin{abstract}
Introduction: Dental fluorosis is endemic in the Rift Valley in Africa, especially around volcanic areas, due to the high fluoride content in daily drinking water.

Objective: This study evaluates the oral health status and types of occlusion in a school population, and to assess the possible association between dental fluorosis and other pathologies such as decay, gingivitis and periodontitis.

Material and methods: An observational study of 581 individuals recruited from a public secondary school in Arusha, Northern Tanzania was undertaken. The indices used were: the Silness \& Löe Plaque Index, the Community Periodontal Index and the Decayed/Missing/Filled index. Descriptive statistical analyses were performed and a chi-square test was used to assess the associations between independent variables.

Results: Almost all the school children evaluated (96.73\%) presented Angle class I dental occlusion, and 75.22\% presented some degree of dental fluorosis. Most of the population (511, 87.95\%) showed bleeding on probing. A moderate/high degree of some dental pathology (DMF score) was recorded in $14.46 \%$. The association between dental fluorosis, gingival bleeding and tooth decay indicated a higher concentration of pathology in groups with more severe fluorosis $(p<0.05)$.

Conclusion: In this large population sample, both tooth decay and gingivitis were significantly associated with moderate or severe dental fluorosis.
\end{abstract}

Keywords: Dental fluorosis; caries; periodontal disease; occlusion; community water fluoridation; socio-economic status.

DOI: https://dx.doi.org/10.4314/ahs.v20i1.54

Cite as: Miranda-Rius J, Brunet-Llobet L, Lahor-Soler E, Mrina O, Mashala EI, Mahande MJ. Periodontal and dental conditions of a school population in a volcanic region of Tanzania with highly fluoridated community drinking water. Afri Health Sci. 2020;20(1):476-87. https:/ / dx.doi. org/10.4314/abs.v20i1.54

\section{Corresponding author: \\ Jaume Miranda-Rius, \\ Department of Odontostomatology, \\ Faculty of Medicine and Health Sciences, \\ University of Barcelona}

Feixa Llarga, s/n, 08907 L'Hospitalet de Llobregat,

Barcelona, Catalonia, Spain

Tel: +34934024269 Fax: +34 934035558

e-mail: jmiranda-rius@ub.edu

\section{Introduction}

Dental fluorosis is endemic to the Rift Valley in Africa, especially in volcanic areas, and it has been attributed to the high fluoride content in daily drinking water. In some parts of Tanzania, and particularly in the Arusha region (close to a dormant stratovolcano named Mount Meru), dental fluorosis is considered a health problem ${ }^{1-4}$. Although the World Health Organization (WHO) guidelines for drinking water quality recommend that fluoride concentration in the water supply should be between 0.5

(C) 2020 Miranda-Rius J et al. Licensee African Health Sciences. This is an Open Access article distributed under the terms of the Creative commons Attribution License (https://creativecommons.org/licenses/BY/4.0), which permits unrestricted use, distribution, and reproduction in any medium, provided the original work is properly cited. 
and $1 \mathrm{mg} / 1,{ }^{5}$ the fluoride content of the drinking water in Arusha is approximately $3.6 \mathrm{mg} / \mathrm{l}^{3}$

The Kaloleni Secondary School is a publicly-funded center located in a low-income neighborhood in the city of Arusha, where students and their families have access only to the public water supply. For these reasons, the school is an ideal setting for the study of dental fluorosis in Northern Tanzania.

Dental caries remains the world's most prevalent disease, affecting billions of people, especially children. ${ }^{6-10} \mathrm{Al}-$ though the number of decayed, missing and filled teeth has fallen in many countries over the last three decades, a growing number of studies have observed increases in these rates in a small section of the population, above all among lower socioeconomic groups. ${ }^{10-14}$ Numerous studies have attempted to correlate caries with dental fluorosis and have reported changes in the risk of decay depending on the degree of severity of the condition. ${ }^{15-23}$

Fewer studies have explored the association between dental fluorosis with periodontitis. The role of some of the etiological factors of periodontal disease such as age, gender, ethnicity, socio-economic status, lifestyle, smoking and oral hygiene has been studied in some populations in India ${ }^{24,25}$ but the effect of fluoride on periodontal tissue remains controversial, even though its association with tooth decay is well established. ${ }^{26}$ The epidemiological data regarding the periodontal status of individuals living in areas with highly fluoridated water are inconsistent. As regards malocclusion, few recent investigations have analyzed and classified dental occlusion in school populations in northern Tanzania. ${ }^{27-29}$

The objectives of the study were, on the one hand, to evaluate the oral health status and types of occlusion in this population, and to assess the possible association between dental fluorosis and other pathologies such as decay, gingivitis and periodontitis.

\section{Methods}

We performed a cross-sectional study at the Kaloleni secondary school as part of the KiliBarnaDental Project, a health promotion intervention carried out in Arusha, northern Tanzania during the 2015-2016 school year. The sample in this observational study comprised 581 individuals.

\section{Study area}

The epidemiological characteristics of the sample are representative of the Kaloleni neighborhood, which has a population of 11,651 inhabitants of low socio-economic status. The World Bank Country classification defines the United Republic of Tanzania as a low-income economy. ${ }^{30}$ Arusha and its area of influence has a population of approximately one million inhabitants, and mean per capita annual income is 499USD.

We stress that our study was part of a non-for-profit project which was previously approved by the health authorities of Arusha City Council. Permission was obtained from the regional health authorities to conduct the study (Ethical clearance certificate, Ref. No. CD / E.10/39/131) and parents of the prospective students were asked to give their consent. The assessments were carried out consecutively by two examiners who had been trained in the use of the measurement system before the recording of the data. Finally, for each participant we wrote a report indicating his/her diagnostic and therapeutic needs.

\section{Study population}

The homogenous sampling in this study was crucial in order to minimize the effect of other confounding factors such as socioeconomic status, sugar intake, and tooth brushing. In fact, the students included were all of low socioeconomic status, ate the basic local diet without refined sugar, and only occasionally brushed their teeth. The study population was made up of healthy individuals without toxic habits, who only used the public water supply for drinking and/or cooking. According to the Arusha Urban Water Supply and Sanitation Authority (AUWSA), the water consumed by this population had a fluoride concentration of $3.6 \mathrm{mg} / 1$. $^{31,32}$

\section{Measurements}

The indices used were: the Silness \& Loe Index (PI) to evaluate oral hygiene. ${ }^{33}$ Assessment of Periodontal status was done using Community Periodontal Index (CPI) modified (Gingival bleeding and periodontal pockets) by the World Health Organization (WHO) Oral Health Assessment Form, 2013. ${ }^{34}$ The Decayed, Missing, Filled $(\mathrm{DMF})^{35}$ index to determine the prevalence of tooth decay and dental treatment needs, and the Thylstrup-Fejerskov Index (TF) ${ }^{36}$ to establish the degree of fluorosis. Finally, the index of restoration $(\mathrm{IR} \%)(\mathrm{IR} \%=[\mathrm{F} / \mathrm{DMF}]$ $\mathrm{x} 100)$ was also calculated to evaluate the presence and 
distribution of dental treatments. With regard to occlusion, the discrepancy (diastemas/crowding), overbite, overjet, crossbite and the Angle class were recorded. The probing depth for the CPITN index was measured with a WHO periodontal probe (550B ES, LM Dental, Parainen, Finland).

The assessments were carried out consecutively by two examiners, OM and EIM, who had been trained and calibrated in the use of the measurement system before the recording of the data.

\section{Statistical analysis}

Statistical analyses were performed using Stata version 13.1 (Stata Corp, College Station, TX). Data were cleaned, checked for discrepancies in value labels, missing values and range checks to enhance consistence. Descriptive statistics were summarized using frequencies and proportions for categorical variables while means and standard deviation were used for normally distributed continuous variables. Chi-square tests were used to determine the associations between a set of independent variables and the outcome of interest. A $p$-value of less than 0.05 (twotailed) was considered statistically significant.

\section{Results}

The characteristics of the study participants $(n=581)$ are summarized in Table 1. The mean (SD) age of the participants was 15.69 (1.45 SD) years. Most were aged over 15 $(314,54.04 \%)$ and slightly more than half $(298,51.29 \%)$ were male.

The assessment of dental occlusion indicated that $96.73 \%$ of the population evaluated had an occlusion of Angle class I. Angle classes II and III were observed in $2.75 \%$ and $0.52 \%$ of cases respectively (Table 2 ). With regard to overjet, the population was classified into three categories: edge-to-edge bite (0-1 $1 \mathrm{~mm}$ ) 49.57\%; normal $(2-3 \mathrm{~mm}) 45.95 \%$, and increased $(>3 \mathrm{~mm}) 4.47 \%$. As for overbite, $52.84 \%$ of the population were edge-to-edge $(0-1 \mathrm{~mm}), 46.47 \%$ normal $(2-3 \mathrm{~mm})$, and $0.69 \%$ increased $(>3 \mathrm{~mm})$. No diastemas were observed in $93.29 \%$ of the population (Table 2).
Table 1: Demographic characteristics $(\mathrm{N}=581)$

\begin{tabular}{lc} 
Characteristics & $\mathbf{n} \mathbf{( \% )}$ \\
\hline Age (mean + SD), years & $15.69(1.45)$ \\
$\begin{array}{l}\text { Age category } \\
\leq 15 \text { years }\end{array}$ & \\
$>15$ years & $267(45.96)$ \\
Gender & $314(54.04)$ \\
Female & \\
Male & $283(48.71)$ \\
\hline
\end{tabular}

Table 2: Occlusion characteristics $(\mathrm{N}=581)$

\begin{tabular}{lc} 
Occlusion & $\mathbf{n}(\mathbf{\%})$ \\
\hline Angle class I & $562(96.73)$ \\
Angle class II & $16(2.75)$ \\
Angle class III & $3(0.52)$ \\
Overjet & $\mathbf{n} \mathbf{( \% )}$ \\
\hline Edge-to-edge 0-1mm & $288(49.57)$ \\
Normal 2-3mm & $267(45.95)$ \\
Increased $\geq 4 \mathrm{~mm}$ & $26(4.47)$ \\
Overbite & $\mathbf{n}(\%)$ \\
\hline Edge-to-edge $0-1 \mathrm{~mm}$ & $307(52.84)$ \\
Normal 2-3mm & $270(46.47)$ \\
Increased $\geq 4 \mathrm{~mm}$ & $4(0.69)$ \\
Crossbite & $\mathbf{n} \mathbf{( \% )}$ \\
\hline 0mm & $563(96.90)$ \\
1mm & $18(3.10)$ \\
Diastemas & $\mathbf{n}(\%)$ \\
\hline $0 \mathrm{~mm}$ & $542(93.29)$ \\
$1 \mathrm{~mm}$ & $39(6.71)$
\end{tabular}


The participants' periodontal status is displayed in Table 3. The majority of the participants $(511,87.95 \%)$ had a CPI of 1 (bleeding at probing), and only $1.90 \%$ had periodontal pathological pockets of $4-5 \mathrm{~mm}$ in depth CPI of 2
(Table 3). As for the Plaque Index, 27.19\% of the sample had values of bacterial plaque accumulation above $50 \%$. Fluorosis was observed in $75.22 \%$ of the population: it was mild in $30.81 \%$, moderate in $34.94 \%$ and severe in $9.47 \%$ (Table 4).

Table 3: Periodontal characteristics $(\mathrm{N}=581)$

\begin{tabular}{|c|c|c|c|}
\hline $\begin{array}{l}\text { Community Periodontal } \\
\text { Index (CPI) }\end{array}$ & $\mathrm{n}(\%)$ & Plaque Index (PI) & $(\%)$ \\
\hline Score 0 & $59(10.15)$ & $<25 \%$ & $68(11.70 \%)$ \\
\hline Score 1 & $511(87.95)$ & $25-50 \%$ & $355(61.10)$ \\
\hline Score 2 & $11(1.90)$ & $50-75 \%$ & $148(25.47)$ \\
\hline Score 3 & 0 & $>75 \%$ & $10(1.72$ \\
\hline Score $<2$ & $570(98.10)$ & Score $\leq 50 \%$ & $423(72.81)$ \\
\hline Score $\geq 2$ & $11(1.90)$ & Score $>50 \%$ & $158(27.19)$ \\
\hline
\end{tabular}

Score 0: No sign of disease; Score 1: Gingival bleeding after gentle probing; Score 2: Teeth with shallow pocket 4 to $5 \mathrm{~mm}$ deep; Score 3 : Teeth with deep pocket $6 \mathrm{~mm}$ or more.

Table 4: Dental fluorosis distribution $(\mathrm{N}=581)$

Dental fluorosis $\quad \mathrm{n}(\%)$

\begin{tabular}{lc}
\hline $0=$ No fluorosis & $144(24.78)$ \\
$1=$ Mild fluorosis & $179(30.81)$ \\
$2=$ Moderate fluorosis & $203(34.94)$ \\
$3=$ Severe fluorosis & $55(9.47)$ \\
Fluorosis Mean (SD) & $1.29(0.944)$ \\
\hline
\end{tabular}

No fluorosis (value 0 ) = score of 0 on the Thylstrup-Fejerskov(TF) Index Mild fluorosis (1)= score of 1-3 on the Thylstrup-Fejerskov (TF) Index Moderate fluorosis (2) = score of 4-5 on the Thylstrup-Fejerskov (TF) Index Severe fluorosis (3) $=$ score of (6-9 on the Thvlstrun-Feierskov (TF) Index

Regarding the prevalence of tooth decay and dental treatment needs (the DMF score), table 5 shows the distribution of decayed, missing and filled teeth and the percentage of individuals affected by the different pathologies.
The DMF scores indicated the following rates of pathology: zero (value $=0$ ) in $54.56 \%$, mild (value $=1-2$ ) in $30.98 \%$ and moderate/high (value $>2$ ) in $14.46 \%$ (Table 5). 
Table 5: Dental characteristics of the study participants $(N=581)$

\begin{tabular}{lc|ll} 
Criteria Index & $\mathbf{n}(\mathbf{\%})$ & Criteria Index & $\mathbf{n ~ ( \% )}$ \\
\hline D (Decayed) & & DMF score & \\
0 & $347(59.72)$ & 0 & $317(54.56)$ \\
1 & $98(16.87)$ & 1 & $103(17.73)$ \\
2 & $66(11.36)$ & 2 & $77(13.25)$ \\
3 & $29(4.99)$ & 3 & $31(5.34)$ \\
4 & $22(3.79)$ & 4 & $26(4.48)$ \\
5 & $8(1.38)$ & 5 & $12(2.07)$ \\
6 & $7(1.20)$ & 6 & $7(1.20)$ \\
8 & $2(0.34)$ & 7 & $3(0.52)$ \\
9 & $2(0.34)$ & 8 & $2(0.34)$ \\
M (Missing) & & 9 & $1(0.17)$ \\
0 & $552(95.01)$ & 10 & $1(0.17)$ \\
1 & $22(3.79)$ & 13 & $1(0.17)$ \\
2 & $5(0.86)$ & & \\
4 & $1(0.17)$ & & \\
5 & $1(0.17)$ & \multicolumn{2}{|l}{} \\
F (Filled) & & DMF score & \\
0 & $563(96.90)$ & 0 (No pathology) & $317(54.56)$ \\
1 & $13(2.24)$ & $1-2$ & $180(30.98)$ \\
2 & $1(0.17)$ & $>2$ & $1.147(1.666)$ \\
3 & $2(0.34)$ & &
\end{tabular}

Overall, our sample presented a DMF pathology rate per patient of 1.147. Both the overall DMF pathology rate and the rates for the individual $\mathrm{D}, \mathrm{M}$, and $\mathrm{F}$ values in- creased in line with the severity of fluorosis (Table 6). The index of restoration (IR\%) of the study population was only $4.8 \%$.

Table 6: Patient pathology rates (Decayed (D), Missing (M), Filled (F) and Overall DMF)

\begin{tabular}{lcccc} 
& $\begin{array}{c}\text { No } \\
\text { Fluorosis } \\
\mathbf{n = 1 4 4}\end{array}$ & $\begin{array}{c}\text { Mild } \\
\text { Fluorosis } \\
\mathbf{n = 1 7 9}\end{array}$ & $\begin{array}{c}\text { Moderate } \\
\text { Fluorosis } \\
\mathbf{n = 2 0 3}\end{array}$ & $\begin{array}{c}\text { Severe } \\
\text { Fluorosis } \\
\mathbf{n = 5 5}\end{array}$ \\
\hline Decay (n) & 71 & 153 & 210 & 87 \\
Rate D/Patient & 0.49 & 0.85 & 1.03 & 1.58 \\
\hline Missing (n) & 12 & 7 & 15 & 7 \\
Rate M/Patient & 0.08 & 0.04 & 0.07 & 0.13 \\
\hline Filled (n) & 2 & 5 & 11 & 12 \\
Rate F/Patient & 0.01 & 0.02 & 0.05 & 0.22 \\
\hline DMF (n) & 85 & 165 & 236 & 106 \\
Rate DMF/Patient & 0.590 & 0.921 & 1.16 & 1.92 \\
\hline D: decay; M: missing; F: filled; DMF: overall decayed, missing, and filled; Pat: patients.
\end{tabular}


With regard to the accumulated distribution of the DMF score according to individuals and teeth affected, $83.52 \%$ of dental pathology was recorded in $27.67 \%$ of the school children examined (Table 7).
Factors such as age, Plaque Index (PI), CPI, and DMF score were significantly associated with dental fluorosis $(p<0.05)$. However, there was no significant association between dental fluorosis and gender $(\chi 2 ; p>0.05)$ (Table 8).

Table 7: Accumulated percentages of DMF scores, according to patients and teeth affected.

\begin{tabular}{cccc|ccc}
\multicolumn{4}{c}{ Patients } & \multicolumn{3}{c}{ Teeth DMF } \\
DMF & $\mathbf{n}$ & $\mathbf{\%}$ & Accumulated \% & $\mathbf{n}$ & \% & Accumulated \% \\
\hline 13 & 1 & 0.17 & 0.17 & 13 & 2.08 & 2.08 \\
12 & 0 & 0 & 0.17 & 0 & 0 & 2.08 \\
11 & 0 & 0 & 0.17 & 0 & 0 & 2.08 \\
10 & 1 & 0.17 & 0.34 & 10 & 1.60 & 3.68 \\
9 & 1 & 0.17 & 0.51 & 9 & 1.44 & 5.12 \\
8 & 2 & 0.34 & 0.85 & 16 & 2.56 & 7.68 \\
7 & 3 & 0.51 & 1.36 & 21 & 3.36 & 11.04 \\
6 & 7 & 1.20 & 2.56 & 42 & 6.72 & 17.76 \\
5 & 12 & 2.06 & 4.62 & 60 & 9.60 & 27.36 \\
4 & 26 & 4.47 & 9.09 & 104 & 16.64 & 44.0 \\
3 & 31 & 5.33 & 14.42 & 93 & 14.38 & 58.88 \\
2 & 77 & 13.25 & 27.67 & 154 & 24.64 & 83.52 \\
1 & 103 & 17.73 & 45.40 & 103 & 16.48 & 100 \\
0 & 317 & 54.60 & 100 & 0 & 0 & 100 \\
\hline Total & 581 & 100 & & 625 & 100 & \\
\hline
\end{tabular}

Table 8: Factors associated with fluoride concentration $(\mathrm{N}=581)$

\begin{tabular}{|c|c|c|c|c|c|c|}
\hline Age & Total & $\begin{array}{c}\text { No } \\
\text { Fluorosis }\end{array}$ & $\begin{array}{l}\text { Mild } \\
\text { Fluorosis }\end{array}$ & $\begin{array}{l}\text { Moderate } \\
\text { Fluorosis }\end{array}$ & $\begin{array}{l}\text { Severe } \\
\text { Fluorosis }\end{array}$ & $p$-values* \\
\hline $\begin{array}{l}>15 \\
\text { Gender }\end{array}$ & $\begin{array}{l}267 \\
314\end{array}$ & $\begin{array}{l}56(20.97) \\
88(28.03)\end{array}$ & $\begin{array}{l}92(34.36) \\
87(27.71)\end{array}$ & $\begin{array}{c}104 \\
(38.95) \\
99(31.53)\end{array}$ & $\begin{array}{c}15(5.62) \\
40(12.74)\end{array}$ & $0.002 *$ \\
\hline $\begin{array}{l}\text { Female } \\
\text { Male } \\
\text { CPI }\end{array}$ & $\begin{array}{l}283 \\
298\end{array}$ & $\begin{array}{l}67(23.67) \\
77(25.84)\end{array}$ & $\begin{array}{l}93(32.86) \\
86(28.86)\end{array}$ & $\begin{array}{c}95(33.57) \\
108 \\
(36.24)\end{array}$ & $\begin{array}{l}28(9.89) \\
27(9.06)\end{array}$ & $0.698^{*}$ \\
\hline $\begin{array}{l}\text { Score } \leq 2 \\
\text { Score }>2 \\
\text { Plaque } \quad \text { Index } \\
\text { (PI) }\end{array}$ & $\begin{array}{c}570 \\
11\end{array}$ & $\begin{array}{c}142 \\
(24.91) \\
2(18.18)\end{array}$ & $\begin{array}{c}170 \\
(29.83) \\
9(81.82)\end{array}$ & $\begin{array}{c}203 \\
(35.61) \\
0(0)\end{array}$ & $\begin{array}{c}55(9.65) \\
0(0)\end{array}$ & $0.044^{*}$ \\
\hline $\begin{array}{l}\text { Score } \leq 50 \% \\
\text { Score }>50 \% \\
\text { DMF score }\end{array}$ & $\begin{array}{l}423 \\
158\end{array}$ & $\begin{array}{c}112 \\
(26.48) \\
32(20.25)\end{array}$ & $\begin{array}{c}140 \\
(33.10) \\
39(24.68)\end{array}$ & $\begin{array}{c}140 \\
(33.10) \\
63(39.87)\end{array}$ & $\begin{array}{c}31(7.33) \\
24(15.19)\end{array}$ & $0.004^{*}$ \\
\hline $\begin{array}{l}0 \text { (No pathology) } \\
1-2 \\
>2\end{array}$ & $\begin{array}{c}317 \\
180 \\
84\end{array}$ & $\begin{array}{l}97(30.60) \\
36(20.00) \\
11(13.10)\end{array}$ & $\begin{array}{l}97(30.60) \\
61(33.89) \\
21(25.00)\end{array}$ & $\begin{array}{l}99(31.23) \\
68(37.78) \\
36(42.86)\end{array}$ & $\begin{array}{c}24(7.57) \\
15(8.33) \\
16(19.05)\end{array}$ & $<0.001^{*}$ \\
\hline
\end{tabular}

${ }^{*} p \leq 0.05$ (Chi-square tests). 
The association between missing, filled and overall DMF and dental fluorosis is shown in Table 9. There was a statistically significant association between fluorosis and decayed, missing, filled scores and overall DMF $(p<0.05)$.
The results showed that groups with more severe degrees of fluorosis had higher rates of dental pathology (Table 9). There was no significant association between dental pathology (DMF score) and the age of the study population $(p=0.876)$ (Table 10).

Table 9: Dental pathology and dental fluorosis

\begin{tabular}{|c|c|c|c|c|c|c|}
\hline D & Total & $\begin{array}{c}\text { No } \\
\text { Fluorosis }\end{array}$ & $\begin{array}{c}\text { Mild } \\
\text { Fluorosis }\end{array}$ & $\begin{array}{l}\text { Moderate } \\
\text { Fluorosis }\end{array}$ & $\begin{array}{c}\text { Severe } \\
\text { Fluorosis }\end{array}$ & $\begin{array}{c}p- \\
\text { values* }\end{array}$ \\
\hline 0 & 347 (59.72) & $105(72.92)$ & $105(58.66)$ & $110(54.19)$ & $27(49.09)$ & \multirow{9}{*}{$<0.001 *$} \\
\hline 1 & $98(16.87)$ & $20(13.89)$ & 32 (17.88) & 37 (18.23) & $9(16.36)$ & \\
\hline 2 & $66(11.36)$ & $11(7.64)$ & $24(13.41)$ & $26(12.81)$ & $5(9.09)$ & \\
\hline 3 & $29(4.99)$ & $4(2.78)$ & 7 (3.91) & $13(6.40)$ & $5(9.09)$ & \\
\hline 4 & $22(3.79)$ & $3(2.08)$ & 7 (3.91) & $10(4.93)$ & $2(3.64)$ & \\
\hline 5 & $8(1.38)$ & $1(0.69)$ & $0(0)$ & $3(1.48)$ & $4(7.27)$ & \\
\hline 6 & $7(1.20)$ & $0(0)$ & $4(2.23)$ & $3(1.48)$ & $0(0)$ & \\
\hline 8 & $2(0.34)$ & $0(0)$ & $0(0)$ & $0(0)$ & $2(3.64)$ & \\
\hline 9 & $2(0.34)$ & $0(0)$ & $0(0)$ & $1(0.49)$ & $1(1.82)$ & \\
\hline \multicolumn{7}{|c|}{ M (Missing) } \\
\hline 0 & $552(95.01)$ & $138(95.83)$ & $173(96.65)$ & $192(94.58)$ & $49(89.09)$ & \multirow{6}{*}{$0.033^{*}$} \\
\hline 1 & $22(3.79)$ & $2(1.39)$ & $5(2.79)$ & $10(4.93)$ & $5(9.09)$ & \\
\hline 2 & $5(0.86)$ & $3(2.08)$ & $1(0.56)$ & $0(0)$ & $1(1.82)$ & \\
\hline 4 & $1(0.17)$ & $1(0.69)$ & $0(0)$ & $0(0)$ & $0(0)$ & \\
\hline 5 & $1(0.17)$ & $0(0)$ & $0(0)$ & $1(0.49)$ & $0(0)$ & \\
\hline \multicolumn{6}{|c|}{ F (Filled) } & \\
\hline 0 & $563(96.90)$ & $142(98.61)$ & $174(97.21)$ & $197(97.04)$ & $50(90.91)$ & \multirow{7}{*}{$0.044^{*}$} \\
\hline 1 & $13(2.24)$ & $2(1.39)$ & $5(2.79)$ & 4 (1.97) & $2(3.64)$ & \\
\hline 2 & $1(0.17)$ & $0(0)$ & $0(0)$ & $1(0.49)$ & $0(0)$ & \\
\hline 3 & $2(0.34)$ & $0(0)$ & $0(0)$ & $0(0)$ & $2(3.64)$ & \\
\hline 4 & $1(0.17)$ & $0(0)$ & $0(0)$ & $0(0)$ & $1(1.82)$ & \\
\hline 5 & $1(0.17)$ & $0(0)$ & $0(0)$ & $1(0.49)$ & $0(0)$ & \\
\hline \multicolumn{6}{|c|}{ DMF } & \\
\hline 0 & $317(54.56)$ & $97(67.36)$ & $97(54.19)$ & $99(48.77)$ & $24(43.64)$ & \multirow{12}{*}{$0.001 *$} \\
\hline 1 & $103(17.73)$ & $20(13.89)$ & 35 (19.55) & $41(20.20)$ & $7(12.73)$ & \\
\hline 2 & 77 (13.25) & $16(11.11)$ & $26(14.53)$ & $27(13.30)$ & $8(14.55)$ & \\
\hline 3 & $31(5.34)$ & $4(2.78)$ & $8(4.47)$ & $15(7.39)$ & $4(7.27)$ & \\
\hline 4 & $26(4.48)$ & $6(4.17)$ & $8(4.47)$ & $9(4.43)$ & $3(5.45)$ & \\
\hline 5 & $12(2.07)$ & $1(0.69)$ & $1(0.56)$ & $7(3.45)$ & $3(5.45)$ & \\
\hline 6 & $7(1.20)$ & $0(0)$ & $3(1.68)$ & $2(0.99)$ & $2(3.64)$ & \\
\hline 7 & $3(0.52)$ & $0(0)$ & $1(0.56)$ & $1(0.49)$ & $1(1.82)$ & \\
\hline 8 & $2(0.34)$ & $0(0)$ & $0(0)$ & $0(0)$ & $2(3.64)$ & \\
\hline 9 & $1(0.17)$ & $0(0)$ & $0(0)$ & $1(0.49)$ & $0(0)$ & \\
\hline 10 & $1(0.17)$ & $0(0)$ & $0(0)$ & $1(0.49)$ & $0(0)$ & \\
\hline 13 & $1(0.17)$ & $0(0)$ & $0(0)$ & $0(0)$ & $1(1.82)$ & \\
\hline
\end{tabular}


Table 10: Dental pathology and population age $(\mathrm{N}=581)$

\begin{tabular}{lcccc}
$\begin{array}{l}\text { Criterion Index } \\
\text { DMF index score }\end{array}$ & Total & $\leq 15$ years & $>15$ years & $p$-value* \\
\hline 0 & 317 & $147(46.37)$ & $170(53.63)$ & \\
1 & 103 & $43(41.75)$ & $60(58.25)$ & \\
2 & 77 & $40(51.95)$ & $37(48.05)$ & \\
3 & 31 & $15(48.39)$ & $16(51.61)$ & \\
4 & 26 & $12(46.15)$ & $14(53.85)$ & \\
5 & 12 & $5(41.67)$ & $7(58.33)$ & \\
6 & 7 & $2(28.57)$ & $5(71.43)$ & 0.876 \\
7 & 3 & $2(66.67)$ & $1(33.33)$ & \\
8 & 2 & $1(50.00)$ & $1(50.00)$ & \\
9 & 1 & $0(0)$ & $1(100)$ & \\
10 & 1 & $0(0)$ & $1(100)$ & \\
11 & 0 & $0(0)$ & $0(0)$ & \\
12 & 0 & $0(0)$ & $0(0)$ \\
13 & 1 & $0(0)$ & $1(100)$ & \\
\hline${ }^{*} p \leq 0.05$ (Chi-square tests); Criterion index: DMF index score &
\end{tabular}

\section{Discussion}

Fluoride may be consumed via drinking water, or via food and oral hygiene products. Interestingly, some studies carried out in Northern Tanzania have reported similar prevalence and severity of dental fluorosis in areas with substantially different concentrations of fluoride in drinking water, (e.g. Kibosho $0.2 \mathrm{mg} / 1$ versus Arusha $3.6 \mathrm{mg} / \mathrm{l}$ ). Various studies have reported similar effects in popula- tions that use "magadi", a potash (trona) salt, to cook certain foods. ${ }^{37-41}$

In order to be able to relate fluorosis and tooth decay, it is important to establish the effects of the fluoride ion on dental tissues (Figure 1). Fluoride participates in many aspects of the formation of calcium phosphate and has notable effects on the process, nature and properties of the mineral tissue formed. It is well known that fluoride reduces the volume of the crystal and increases the structural stability. ${ }^{42}$
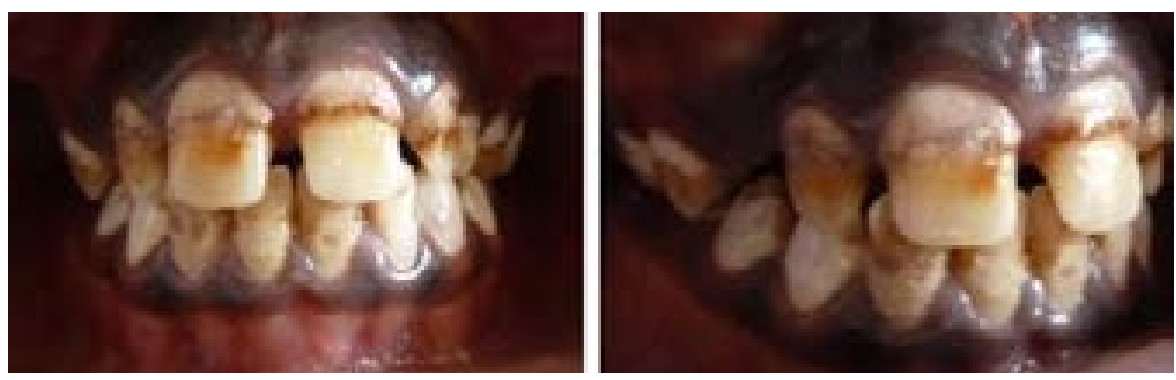

Figure 1. Severe dental fluorosis: In the enamel surfaces note the roughness, spots, and plaque accumulation.

In the process of enamel mineralization during amelogenesis, the fluoride ions are incorporated into the mineralized enamel, reducing its solubility as well as improving the interaction of the mineral-protein matrix. In contrast, an excess of fluoride leads to a defective formation of the enamel, thus slowing the maturation of the tissue. ${ }^{43}$
The critical period for the development of dental fluorosis in permanent dentition is the first six years of life. Many studies have assessed the prevalence of tooth decay both in populations that present high levels of fluorine and in others that present lower levels. ${ }^{15-23}$ In 1994, a World Health Organization Expert Committee published 
a consensus report on the role of fluoride in the promotion of oral health all over the world. ${ }^{44}$

Assessing the prevalence of caries in schoolchildren living in areas with different levels of fluoride, Sukhabogi et al. ${ }^{17}$ observed the highest prevalence in the group in the low fluoride area, followed by the groups in the high and very high area. The lowest rates of decay were found in the medium fluoride area. Thus, an excess of fluoride related to severe dental fluorosis increases the risk of decay. However, Shanthi et al. ${ }^{18}$ observed a higher prevalence of caries in population groups with suboptimal fluorine levels. Aimée et al. ${ }^{19}$ conclude in their study that combined fluoride exposure through fluoridated water, food cooked with fluoridated water and twice daily brushing with conventional fluoride-containing toothpaste from an early age are recommended to control the progression of tooth decay.

Most cases of fluorosis are mild and tend to cause minimal aesthetic compromise, although in certain areas severe cases may be recorded. Discussing the rising prevalence of fluorosis over the past 50 years, Rozier et al, ${ }^{20}$ conclude that the benefits of fluoride during the critical phases of enamel development outweigh the risks. Jackson et al. $^{21}$ reported that during the period of enamel formation fluorine concentrations of $1 \mathrm{ppm}$ in drinking water, or even lower, may cause mild fluorosis. However, infants who drink water with fluoride levels of $1 \mathrm{ppm}$ present protection against decay compared to those who drink water with fluoride levels practically zero. The authors concluded that although mild fluorosis may cause slight aesthetic effects, the protective role of fluoride against caries should prevail.

Similarly, Molina-Frechero et al. ${ }^{22}$ argue that exposure to different sources of fluoride is a risk factor for the development of fluorosis and a benefit for dental caries, and Iida \& Kumar ${ }^{23}$ observed that molars with fluorosis were more resistant to caries than those without. In contrast, our research shows that patients with more severe fluorosis present the highest rates of decayed, missing and filled teeth. Our study suggests that only mild fluorosis provides a certain protective effect against caries. Indeed, in areas with very high concentrations of fluorine, Sukhabogi et al. ${ }^{17}$ observed a high prevalence of caries.

Finally, comparison of the index of restoration (IR\%) in this school age population in Tanzania $(4.8 \%)$ and in an equivalent population from southern Europe (67\%) indicates the great difficulty patients in developing countries in obtaining dental treatment. ${ }^{45}$

Fluoride produces effects on bone tissue that can lead to skeletal fluorosis. The main sign of this metabolic alteration is osteosclerosis, mainly affecting the joints. The result is usually ligament calcification accompanied by osteopenia, osteoporosis and osteomalacia of varying degrees of severity. ${ }^{46,47}$

Skeletal fluorosis usually presents in individuals with a daily fluoride intake of 36-54 mg for at least 10 years. ${ }^{46,48}$ Few studies have investigated the relationship between periodontal disease and fluoride intake. A lower prevalence of shallow pockets has been observed in study populations where the concentration of fluoride in drinking water ranged from 1.83 to $2.01 \mathrm{ppm}$, leading to the conclusion that fluoride in water was beneficial for periodontal tissues. ${ }^{24,25}$ Similarly, Anurada et al. (2002) observed that increasing the concentration of fluoride reduced the prevalence of periodontal disease. ${ }^{49}$ For their part, Megalamanegowdru (2012) reported that the severity of periodontal disease was inversely related to the fluoride concentration in drinking water. ${ }^{50}$ However, Vandana \& Reddyobserved (2007) observed that increasing the degree of fluorosis also increased the prevalence of periodontitis. ${ }^{24}$ In our study, we found higher Plaque Index scores and a higher prevalence of bleeding on probing in patients with moderate fluorosis; this may be related with the development of rougher and more retentive dental surfaces when these teeth are affected by fluorosis. According to the CPI, periodontal pockets are not recorded in individuals younger than 15 years of age, ${ }^{34}$ but in our group some students were above this threshold and so finally we decided to record these data.

Our study provides a description of the type of dental occlusion in the child and adolescent population in this area of Tanzania. Almost all the school children evaluated $(96.73 \%)$ presented Angle class I dental occlusion. We have not found any previous studies of the dental relationship of the maxillary and mandibular arches in this country. In one study in the Nigerian population, some authors observed a predominance of Angle class II and III malocclusions with respect to type $I .{ }^{51}$ In contrast, in another Nigerian population a predominance of Angle class I occlusion was observed. ${ }^{52}$ Other studies have examined the differences between ethnic groups with re- 
gard to craniofacial measurements and angles, which help to describe facial morphology. ${ }^{53}$

This study was part of an oral health project, which was previously evaluated and approved by the authorities of Arusha city council. In addition to the clinical examination of the students, we gave lectures/seminars to the entire school community, including teachers and administrative staff. The main themes of this oral education program were dental plaque, caries, periodontal disease, and oral hygiene instructions. We also provided dental hygiene material for conducting practical workshops in small groups. Finally, for each participant we wrote a report indicating his/her diagnostic and therapeutic needs. In these areas with high rates of fluorosis, economical strategies for reducing the level of fluoride in drinking water should be promoted. At present the only way to minimize endemic fluorosis is to use bottled water, even for cooking, and this represents a huge cost for families of low socio-economic status. It would be useful to assess the feasibility of innovative systems incorporating the use of osmosis membranes to facilitate the purification of water for household use.

\section{Conclusion}

In this broad population sample, both decay and gingivitis were associated with moderate/severe dental fluorosis. The introduction of oral education programs in schools may be an appropriate strategy for improving dental hygiene among the young and for reducing the incidence of future oral pathologies.

\section{Acknowledgments}

Clínics Associats, a well-established Professional Partnership in Terrassa (Barcelona), leads and supports the KiliBarnaDental project at the Soweto General Hospital in Arusha, United Republic of Tanzania, East Africa. The authors thank Mount Meru Hotel, Miguel Torres Foundation and Straumann, SA (Spain) for their contributions.

\section{Author contributions}

JMR and LBL conceived the ideas; OM and EIM collected the data; JMR, LBL, EIM, MJM, and ELS analysed the data; all the authors read and approved the final version of the manuscript.

\section{Abbreviations}

PI: Plaque Index; CPI: Community Periodontal Index;
DMF Decayed, Missing, Filled Index; TF: Thylstrup-Fejerskov Index; (IR\%): Index of Restoration; WHO: World Health Organization; SD: Standard Deviation.

\section{Ethical considerations}

Our study was reviewed and approved by the Arusha City Council prior to its commencement. Ethical clearance certificate, Ref. No. CD / E.10/39/131, was obtained from the Arusha Health and Ethics Committee. Written consent was obtained from all participants prior to oral diagnosis and interviews, after a full explanation of the study objectives. Confidentiality and privacy were guaranteed according to the birth registry protocol. All the parents/legal guardians of the participants were informed of the nature of the study and provided signed informed consent in advance. Hence our research was conducted in full accordance with the World Medical Association Declaration of Helsinki.

\section{Conflicts of interest}

The authors have no conflicts of interest to declare.

\section{Funding}

No funding was obtained for this study.

\section{References}

1. Rango T, Vengosh A, Jeuland M, et al. Fluoride exposure from groundwater as reflected by urinary fluoride and children's dental fluorosis in the Main Ethiopian Rift Valley. Sci Total Environ 2014; 15:188-197 PubMed.

2. Wambu EW, Agong SG, Anyango B, et al. High Fluoride water in Bondo-Rarieda area of Siaya County, Kenya: a hydro-geological implication on public health in the lake Victoria Basin. BMC Public Health 2014; 17:462.

3. Awadia AK, Birkeland JM, Haugejorden O, et al. An attempt to explain why Tanzanian children drinking water containing 0.2 or $3.6 \mathrm{mg}$ fluoride per liter exhibit a similar level of dental fluorosis. Clin Oral Investig 2000; 4: 238-244 PubMed.

4. Jarvis HG, Heslop P, Kisima J, et al. Prevalence and aetiology of juvenile skeletal fluorosis in the south-west of the Hai district, Tanzania -- a community-based prevalence and case-control study. Trop Med Int Health. 2013; 18: 222-229 PubMed.

5. World Health Organization. Guidelines for Drinking Water Quality. 4th edition. Geneve. 2011.

http://www.who.int/water_sanitation_health/publications/dwq-guidelines-4/en/ 
6. Dye BA, Hsu KL, Afful J. Prevalence and Measurement of Dental Caries in Young Children. Pediatr Dent 2015; 37: 200-216 PubMed.

7. Barbosa TS, Gavião MB. Oral health-related quality of life in children: part I. How well do children know themselves? A systematic review. Int J Dent Hyg 2008; 6: 93-99 PubMed.

8. Barbosa TS, Gavião MB. Oral health-related quality of life in children: part II. Effects of clinical oral health status. A systematic review. Int J Dent Hyg 2008; 6: 100-107 PubMed.

9. Barbosa TS, Gavião MB. Oral health-related quality of life in children: part III. Is there agreement between parents in rating their children's oral health-related quality of life? A systematic review. Int J Dent Hyg 2008; 6: 108-113 PubMed.

10. Marthaler TM. Changes in dental caries 1953-2003. Caries Res 2004; 38: 173-181 PubMed.

11. Petersen PE. Sociobehavioural risk factors in dental caries - international perspectives Community. Dent Oral Epidemiol 2005; 33: 274-279.

12. Geyer S, Schneller T, Micheelis W. Social gradients and cumulative effects of income and education on dental health in the Fourth German Oral Health Study. Community Dent Oral Epidemiol 2010; 38: 120-128 PubMed.

13. Pitts N, Amaechi B, Niederman R, et al. Global oral health inequalities: dental caries task group - research agenda. Adv Dent Res 2011; 23: 211-220 PubMed.

14. Do LG. Distribution of caries in children: variations between and within populations. J Dent Res 2012; 91: 536543 PubMed.

15. Moimaz SA, Saliba O, Marques LB, Garbin CA, Saliba NA. Dental fluorosis and its influence on children's life. Braz Oral Res 2015; 29. Jan 13.

16. Simangwa LD, Åstrøm AN, Johansson A, Minja IK, Johansson AK. Oral diseases and socio-demographic factors in adolescents living in Maasai population areas of Tanzania: a cross-sectional study. 2018 Dec 4; 18 (1): 200. 17. Sukhabogi JR, Parthasarathi P, Anjum S, et al. Dental Fluorosis and Dental caries Prevalence among 12 and 15 - Year-Old School Children in Nalgonda District, Andhra Pradesh, India. Ann Med Health Sci Res 2014; 4(Suppl 3): S245-252.

18. Shanthi M, Reddy BV, Venkataramana V, et al. Relationship Between Drinking Water Fluoride Levels, Dental Fluorosis, Dental Caries and Associated Risk Factors in 9-12 Years Old School Children of Nelakondapally Mandal of Khammam District, Andhra Pradesh, India:
A Cross-sectional Survey. J Int Oral Health 2014; 6: 106110 PubMed.

19. Aimée NR, Van Wijk AJ, Maltz M, et al. Dental caries, fluorosis, oral health determinants, and quality of life in adolescents. Clin Oral Investig 2017; 21: 1811-1820 PubMed.

20. Rozier RG, Adair S, Graham F, et al. Evidence-based clinical recommendations on the prescription of dietary fluoride supplements for caries prevention: a report of the American Dental Association Council on Scientific Affairs. J Am Dent Assoc 2010; 141: 1480-1489 PubMed.

21. Jackson RD, Kelly SA, Katz B, et al. Dental fluorosis in children residing in communities with different water fluoride levels: 33-month follow-up. Pediatric Dent 1999; 21: 248-254.

22. Molina-Frechero N, Pierdant-Rodríguez AI, Oropeza-Oropeza A, et al. Fluorosis and dental caries: an assessment of risk factors in Mexican children. Rev Invest Clin 2012; 64: 67-73 PubMed.

23. Iida H, Kumar JV. The association between enamel fluorosis and dental caries in U.S. schoolchildren. $J A m$ Dent Assoc 2009; 140: 855-862 PubMed.

24. Vandana KL, Reddy MS. Assessment of periodontal status in dental fluorosis subjects using community periodontal index of treatment needs. Indian J Dent Res 2007; 18: 67-71 PubMed.

25. Kumar PR, John J. Assessment of periodontal status among dental fluorosis subjects using community periodontal index of treatment needs. Indian J Dent Res 2011; 22: 248-251 PubMed.

26. Singh P, Gupta ND, Bey A. Dental fluorosis and periodontium: A game of shadows? J Oral Biol Craniofac Res 2014; Jan-Apr; 4(1): 47-8.

27. Mugonzibwa EA, Kuijpers-Jagtman AM, van't Hof MA, et al. Need for orthodontic treatment among Tanzanian children. East Afr Med J 2004; 81: 10-15 PubMed. 28. Mugonzibwa EA, Eskeli R, Kuijpers-Jagtman AM, et al. Occlusal characteristics during different emergence stages of the permanent dentition in Tanzanian Bantu and Finnish children. Eur J Orthod 2004; 26: 251-60 PubMed.

29. Kerosuo H, Laine T, Nyyssonen V, et al. Occlusal characteristics in groups of Tanzanian and Finnish urban schoolchildren. Angle Orthod 1991; 61: 49-56 PubMed .

30. World Bank Country and Lending Groups. The World Bank Group - worldbank.org. 2017

https://datahelpdesk.worldbank.org/knowledgebase/ articles/906519-world-bank-country-and-lending-groups (Last accessed June 2017). 
31. Malago J, Makoba E, Muzuka ANN. Fluoride levels in surface and groundwater in Africa: A review. Am J Water Sci Eng 2017; 3: 1-17 PubMed.

32. Fawell J, Bailey K, Chilton J, et al. Fluoride in drinking-water. World Health Organization, Geneva, 2006.

33. Löe, H. The Gingival Index, the Plaque Index and the Retention Index Systems. J Periodontol 1967; 38 (Suppl.), 610-616.

34. World Health Organization. Oral Health Surveys Basic Methods. $5^{\text {th }}$ edition. Geneve. 2013.

35. Klein H, Palmer CE. Studies on dental caries. Pub Health Rep 1938; 53: 1685-1689 PubMed.

36. Thylstrup A, Fejerskov O. Clinical appearance of dental fluorosis in permanent teeth in relation to histologic changes. Community Dent Oral Epidemiol 1978; 6: 315-328. 37. Awadia AK, Bjorvatn K, Birkeland JM, et al. Weaning food and magadi associated with dental fluorosis in northern Tanzania. Acta Odontol Scand 2000; 58: 1-7 PubMed. 38. van Palenstein Helderman WH, Mabelya L, van't Hof MA, et al. Two types of intraoral distribution of fluorotic enamel. Community Dent Oral Epidemiol 1997; 25: 251-255. 39. van Palenstein Helderman WH, Mkasabuni E, Mjengera HJ, et al. Severe dental fluorosis in children consuming fluoride containing magadi salt. Tanzania Dent J 1997; 8: 16-20 PubMed.

40. Yoder KM, Mabelya L, Robison VA, et al. Severe dental fluorosis in a Tanzanian population consuming water with negligible fluoride concentration. Community Dent Oral Epidemiol 1998; 26: 382-393.

41. Awadia AK, Haugejorden O, Bjorvatn K, et al. Vegetarianism and dental fluorosis among children in a high fluoride area of northern Tanzania. Int J Paediatr Dent 1999; 9: 3-11 PubMed.

42. Aoba T, Fejerskov O. Dental fluorosis: chemistry and biology. Crit Rev Oral Biol Med 2002; 13: 155-170.

43. Whitford GM. Determinants and mechanisms of enamel fluorosis. Ciba Foundation Symp 205. 1997. Chichester: Wiley, pp. 226-241.
44. World Health Organization Technical Report Series. 846. Fluoride and oral health. Report of a WHO Expert Committee on Oral Health status and Fluoride use. Geneva. 1994. Available at: http://apps.who.int/iris/bitstream/10665/39746/1/WHO_TRS_846.pdf

45. Bravo Pérez M, Almerich Silla JM, Ausina Márquez V, et al. Encuesta de salud oral en España 2015. RCOE 2016; 21 (Suppl 1): 8-48.

46. Junrui P, Bingyun L, Yanhui G, et al. Relationship between fluoride exposure and osteoclast markers during RANKL-induced osteoclast differentiation. Environ Toxicol Pharmacol 2016; 46: 241-245.

47. Boivin G, Chavassieux P, Chapuy MC, et al. Skeletal fluorosis: histomorphometric findings. J Bone Miner Res 1990; 5 (Suppl. 5): S185-S189

48. Sarala Kumari D, Ramakrishna Rao P. Endemic fluorosis in the village Ralla Ananthapuram in Andhra Pradesh, an epidemiological study. Fluoride 1993; 26: 177180 PubMed.

49. Anuradha KP, Chadrashekar J, Ramesh N. Prevalence of periodontal disease in endemically fluorosed areas of Davangere Taluk, India. Indian J Dent Res 2002; 13: 15-19 PubMed.

50. Megalamanegowdru J, Ankola AV, Vathar J, et al. Periodontal health status among permanent residents of low, optimum and high fluoride areas in Kolar District, India. Oral Health Prev Dent 2012; 10: 175-183.

51. Dosumu OO, Ikusika OF. An assessment of interocclusal space in a dentate Nigerian population. Niger Postgrad Med J 2013; 20: 315-318 PubMed.

52. Utomi IL, Onyeaso CO. Anteroposterior, vertical and space malocclusions in adolescents with special needs in Lagos, Nigeria. Odontostomatol Trop 2011; 34: 17-23 PubMed.

53. Farkas LG, Katic MJ, Forrest CR, et al. International anthropometric study of facial morphology in various ethnic groups/races. J Craniofac Surg 2005; 16: 615-646 PubMed. 